EIS $11 / 2017$

Efficiency

Assessment

Concept Model for

Financial Alliances:

Bancassurance in

Baltic Pension Fund

Management

Submitted

04/2017

Accepted for

publication

08/2017
Efficiency Assessment

Concept Model for Financial

Alliances: Bancassurance

in Baltic Pension Fund

Management

\section{Ilja Arefjevs}

BA School of Business and Finance, K.Valdemara 161, Riga, LV1013, Latvia, ilja.arefjevs@inbox.lv

The purpose of the article is to develop and implement an efficiency assessment concept model for financial alliances based on efficiency assessment of Bancassurance in the pension fund management in the Baltic countries.

Tasks of the research include explaining the topicality, studying the Bancassurance, review of two frontier based efficiency measurement techniques - stochastic frontier analysis and data envelopment analysis and its applicability for banking, insurance and pension funds industry as well as Bancassurance efficiency assessment by using stochastic frontier analysis and data envelopment analysis.

Methods used are qualitative- monographic method, literature review, document analysis, data evaluation. Quantitative- econometric techniques, including regression and correlation analysis, economic modelling techniques, including stochastic frontier analysis and data envelopment analysis, descriptive statistics methods, cluster analysis.

Bancassurance was found to be the dominant business model in the pension fund management in Baltics Pension fund management business is very important for financial groups operating in the Baltic countries because it generates very strong return on equity.

Small and medium specialised pension fund management companies proved to be capable of achieving competitive efficiency compared to other companies.

KEYWORDS: Financial alliances, Bancassurance, pension fund management, stochastic frontier analysis, data envelopment analysis.

\title{
Introduction
}

The rapid development of the financial sector posed challenges to scientists, regulators and traditional market players. Even though alliances among various financial companies have been extensively studied (eg., Bancassurance models) and can be grounded on fundamental theories, disruptive innovations in the shape of emerging financial technology companies clearly brought a new perspective extending conventional financial alliances into modern financial eco-systems. The paper is aimed at assessing efficiency of conventional financial alliances such as Bancassurance whilst applying contemporary frontier based methods and further elaborations, which can be also employed in efficiency research of modern financial eco-systems or financial technology companies as components of those. 
Different researchers suggested various definitions for a concept referred in the scientific and business literature to as Bancassurance. Pinter (2013) defined Bancassurance as the means for connecting those kinds of financial services, which could cautiously fulfil financial and insurance needs. Additional and essential elements are stressed out as well -savings, financing and insurance. Based on previous research in the field (eg., Davis, 2007; Clipici and Bolovan, 2012; Preckova, 2016), a following definition of Bancassurance is developed in the context of an alliance between banks and pension fund management companies: Alliance between a bank and pension fund management company assuming either vertical or other type of integration with a purpose of selling of pension fund products and providing related services to customers by exploiting banks' resources and customer relationships.

Bancassurance can be considered to be one of the financial sector convergence examples. The convergence in the financial sector is believed to be caused by the business diversification trend. General diversification topic has been widely studied. The pivotal question of interest is whether diversified firms outperform specialized counterparts. Even though it is more often the case than not, findings of related researches do not always confirm this hypothesis.

Business diversification effects on performance were extensively studied by Rummelt (1974). In his book "Strategy, Structure and Economic Indicators" Rummelt proved, that related (that is integrated) but non-competing diversifiers are capable of achieving better performance than non-related (that is non-integrated) diversifiers. Carter (1977) and Grant and Jammine (1988) also found value creation in diversification. Later on, Berger and Ofek (1995) and Lang and Stulz (1994) made their contribution to the discussion by bringing contradictive findings.

The research problem is to assess whether small and medium specialised pension fund management companies operating in Estonia, Latvia and Lithuania under the Bancassurance are capable of achieving competitive efficiency compared to the one of companies with bigger assets under management and bigger share of non-pension fund management income.

The research tasks include examining the origin of Bancassurance and its development, examining the stochastic frontier analysis (SFA) and data envelopment analysis (DEA) as efficiency analysis methodology and its applicability for banking, insurance and pension funds industry, assessing the efficiency of Bancassurance from the perspective of capability of companies with different volume and scope of operations to achieve competitive efficiency by using SFA and DEA as well as developing efficiency improvement proposals for pension fund management Bancassurance from the perspective of capability of companies with different volume and scope of operations to achieve competitive efficiency.

The research can be seen as consisting of four main stages and review of previous research. The first stage of the research is devoted to establishing theoretical foundations by conducting a literature review - studying the Bancassurance as the business model, studying parametric and non-parametric efficiency assessment methodologies like stochastic frontier analysis and data envelopment analysis. The second stage of the research is the beginning of the empirical part of the research, which starts with a description of a banking environment after the crisis in Europe and Baltics. The third stage is based on quantitative assessment of corporate data of pension fund management companies obtained from annual reports. The regression and correlation analysis is applied in order to examine relationship between variables describing size and scope of operations and variables describing efficiency. Furthermore, pension fund management companies are classified in terms of size and scope of their operations by employing the cluster analysis. Consistency checks of the efficiency scored produced by different models are performed by using a regression analysis. Finally, the fourth stage of the research is devoted to the result discussion and development of recommendations in the research topic. 
The fourth stage research is designed in order to implement the concept model of the research. The concept model of the research is provided under the Figure 1. It presents a logical flow of theoretical and empirical developments of the research as well as demonstrates interrelations between its parts.

Figure 1

Research concept model (prepared by the author,

2017)

\section{Bancassu- rance, Data envelopment analysis and Stochastic frontier analysis}

Figure 2

Bancassurance and its efficiency in the pension fund management (prepared by the author, 2016)

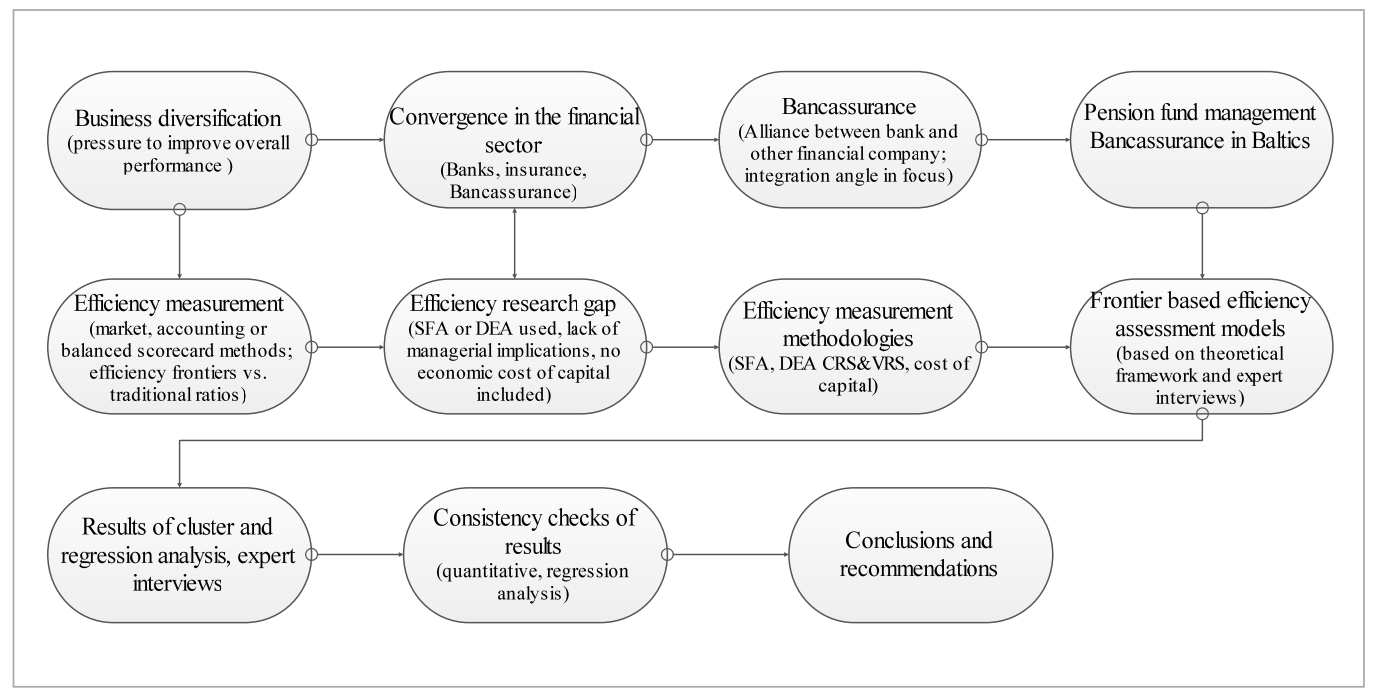

Following methods were used in the research:

_ Qualitative methods: monographic method, literature review, document analysis, and data evaluation.

_ Quantitative methods: regression and correlation analysis, economic modelling techniques, including SFA and DEA, descriptive statistics methods, cluster analysis.

General research period is from 2008 till 2016 while efficiency assessment models are implemented based on financial data from 2009 till 2015.

Based on findings of various researchers provided in the introduction of the research, the Bancassurance illustration in the field of the pension fund management is developed, which is subject to assumptions and limitations of the research. The illustration is provided in the Figure 2.

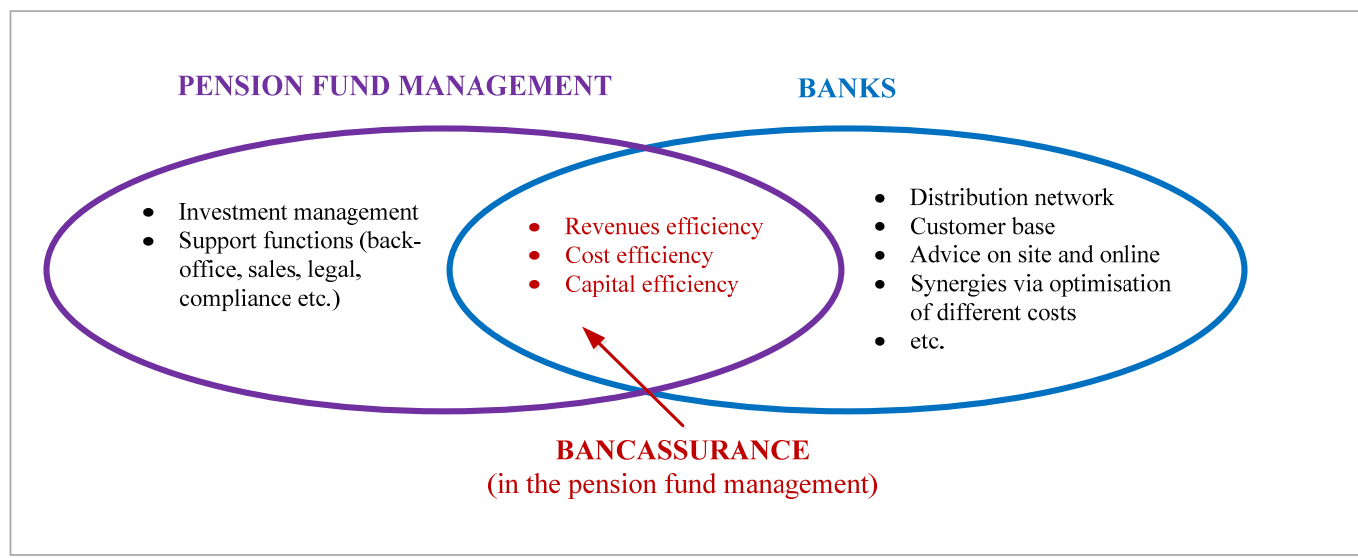


Pension fund management companies ensure their core operations as well as support functions. A bank in its turn employs a distribution network and serves a base of customers in a more efficient manner by offering pension products to its customers. As a result, revenue efficiency (via bigger sales volume), cost efficiency (via smaller sales and other costs) as well as capital efficiency is improved, caused by improvement in two above-mentioned efficiency areas.

Different efficiency measurement methods evolved over time. Studies that compare parametric and non-parametric techniques are Ferrier and Lovell (1990), Sheldon (1994), Resti (1997), Bauer, et. al. (1998), Casu and Girardone (2002), Weill (2004) and Beccalli, et. al. (2006). Some researchers also studied relationship between diversification and performance depending on a size of an insurance company (Berry-Stolzle, et. al., 2013). Du and Sim (2016) examined cross-country evidence on whether the effect of mergers and acquisitions on bank efficiency differs for target versus acquiring banks. To estimate efficiency, researchers employed the DEA approach. Moradi-Motlagh and Babacan (2015) investigated the efficiency levels of Australian banks prior to, during and in the post great financial crisis period by using DEA. Titko, et al., (2014) provided improvement recommendations for efficiency assessment methodology, which is based on DEA VRS models applied for banks operating in Latvia. Aiello and Bonanno (2016) used SFA in conducting the analysis of the level and dynamics of performance small mutual cooperative banks in Italy compared with others and modelling time as a determinant of efficiency of small mutual cooperative banks. SFA was used by Hughes and Mester (2013) in efficiency assessment of large banks.

Quite often, accounting based Bancassurance efficiency measurement has been performed by employing SFA, which was developed by Aigner (Aigner, et. al., 1977) as well as DEA, pioneered by Charnes (Charnes, et. al., 1978). Later both SFA and DEA were used in the Bancassurance efficiency analysis by Bikker (Bikker, Van Leuvensteijn, 2008), Fiordelisi (Fiordelisi, Ricci, 2009), Nawi (Nawi, et. al., 2012) as well as other authors.

Greene (1997) proposed that frontier production function in general can be described as an extension of a regression model. The initial framework on parametric frontier analysis commenced with Farell's (1957) cross-sectional model where goal programming techniques were used to estimate production function where $i=(1,2,3, \ldots, i)$ represents the corresponding producer, $Y$ is the level of output, $X$ refers to a vector of $N$ inputs, $f($.) is the production frontier depending on inputs and technology parameters $(\beta)$ to be estimated. The last term is the technical efficiency of the $i^{\text {th }}$ firm calculated as the ratio of observed output over maximum feasible output:

$$
T E_{i}=\frac{Y_{i}}{f\left(x_{i, \beta} \beta\right)}
$$

Aigner, et. al. (1977), Battese and Corra (1977), Meeusen and Van den Broek (1977) independently proposed to estimate a stochastic production frontier. The model is denoted in logs as (Deutsche Bundesbank, 2006):

$$
\ln y_{j}=\ln x_{j} \beta+v_{j}-u_{j,} \quad \text { (2) }
$$

where $x_{j}$ denotes an input vector for firm $j, v_{j}$ depicts random error added to the non-negative inefficiency term, $u_{i}$. Random error, $v_{i}$, accounts for measurement error and other random factors affecting the value of the output variable, together with the combined effects of unspecified input variables in the production function. The model is stochastic because the upper limit is determined by the stochastic variable: 


$$
\exp \left(x_{j} \beta+v_{j}\right)
$$

The random error, $v_{i}$, can be positive or negative and so the stochastic frontier outputs vary relative to the deterministic part of the frontier model, $\exp (x)$ (Coelli, et. al., 2005).

Data Envelopment Analysis (DEA) was originated by Charnes, Cooper, and Rhodes (1978). The researchers developed the piece-wise-linear convex hull approach to frontier estimation proposed by Farrell (1957) in a model which has an input orientation and assumes constant return to scale, in the following CRS model (Deutsche Bundesbank, 2006). The original CRS model assumes constant return to scale, an inappropriate assumption for most banking studies in general (Hackethal, 2004). Adoption of variable return to scale (VRS) becomes reasonable because it ensures that a firm is compared only with firms of a similar size. The VRS model is assumed to envelope data more closely and thus would compute efficiency scores that are equal or bigger than ones calculated by the CRS model (Banker et al., 1984).

To capture the magnitude of "scale effect", a variable returns to scale (VRS) model, which dismisses the CRS assumption, was developed by Färe, et. al., (1983) and Banker, et. al., (1984). Figure 3 explains the divergence of VRS models from CRS ones.

Figure 3 DEA CRS and VRS models showing combinations of fixed inputs needed to produce output (prepared by the author based on Coelli, et. al., 2005)

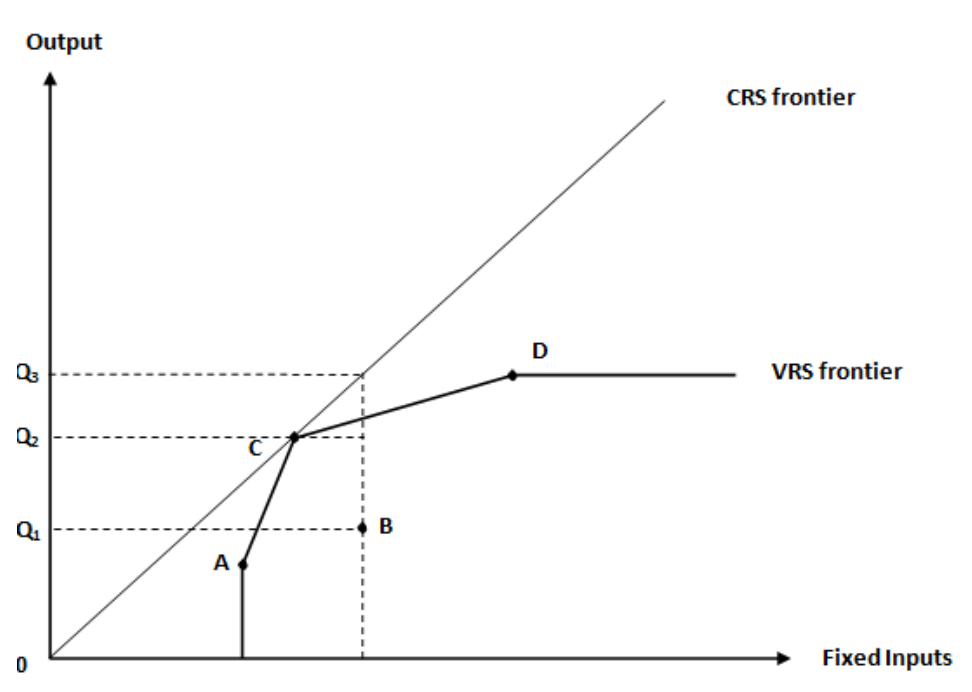

For example, the efficiency at the point $B$ is calculated as a ratio of $Q_{1} / Q_{2}$ for the VRS frontier. In cas of the CRS frontier it is defined as $Q_{1} / Q_{3}$. The VRS frontier takes into account scale efficiency when measuring total efficiency. Linear programming of the VRS model is very similar to the CRS one. Major difference is a so called convexity constraint added to the system:

$$
\sum_{j=1}^{k} \lambda_{j}=1, \text { for } j=1,2 \ldots, k
$$

$$
\text { for } j=1 \text {, for } j=1,2, \ldots ., k \text {. }
$$

The mathematical relationship between the variable and constant return to scale model efficiency measurements can be presented as (Coelli et al., 2005):

$$
T E_{C R S}=T E_{V R S} * S E
$$

where SE defines scale efficiency, meaning that CRS technical efficiency can be split into technical efficiency and scale efficiency. 
The pivotal role in the Baltic banking and as a result pension fund marketplace belongs to players with the Nordic origin while local companies with mixed shareholding structures provide some diversification to the market. The research includes all twenty pension fund management companies, which are presented in the Table 1.

Typically, vast majority of the pension fund management companies covered by the research are integrated with banks (insurance company in case of Ergo Funds) to the closest possible extent, that is via ownership, except Invalda (former Finasta) in Lithuania, MP Pension Fund Baltics and LHV Varahaldus, which distribute most of their pension products outside banking channels. Invalda (former Finasta) in Latvia initially had ownership based integration. However, after the bank belonging to the same financial group (i.e. JSC Latvijas Krājbanka), went bankrupt in late

\begin{tabular}{|c|c|c|c|c|}
\hline Name & Country & $\begin{array}{l}\text { Bancassurance } \\
\text { integration }\end{array}$ & Legal Owner & $\begin{array}{l}\text { Owner's } \\
\text { origin }\end{array}$ \\
\hline CBL Asset Management & Latvia & Ownership & Citadele Bank & Latvia \\
\hline $\begin{array}{l}\text { Swedbank Investment Management } \\
\text { Company }\end{array}$ & Latvia & Ownership & Swedbank Robur & Sweden \\
\hline SEB Wealth Management & Latvia & Ownership & SEB Bank & Sweden \\
\hline DNB Asset Management & Latvia & Ownership & DNB Bank & Norway \\
\hline Nordea Pensions Latvia & Latvia & Ownership & Nordea Life Holding AB & Sweden \\
\hline $\begin{array}{l}\text { Norvik Investment Management } \\
\text { Company }\end{array}$ & Latvia & Ownership & Norvik Bank & Latvia \\
\hline Hipo Fondi & Latvia & Ownership & Hipo and Land Bank ${ }^{*}$ & Latvia \\
\hline Invalda (Finasta) Asset Management & Latvia & $\begin{array}{l}\text { Distribution/ } \\
\text { Ownership }\end{array}$ & Invalda (Finasta) & Lithuania \\
\hline LHV Varahaldus & Estonia & None & LHV Group & Estonia \\
\hline SEB Varahaldus & Estonia & Ownership & SEB Bank & Sweden \\
\hline Danske Capital & Estonia & Ownership & Danske Bank & Denmark \\
\hline Nordea Pensions Estonia & Estonia & Ownership & Nordea Life Holding AB & Sweden \\
\hline Swedbank Investment Funds & Estonia & Ownership & Swedbank Robur & Sweden \\
\hline Ergo Funds & Estonia & Ownership & Ergo Life Insurance & Germany \\
\hline Swedbank Investment Management & Lithuania & Ownership & Swedbank Robur & Sweden \\
\hline DNB Investment Management & Lithuania & Ownership & DNB Bank & Norway \\
\hline MP Pension Funds Baltic & Lithuania & None & MP Bank & Iceland \\
\hline SEB Investment Management & Lithuania & Ownership & SEB Bank & Sweden \\
\hline Invalda (Finasta) Asset Management & Lithuania & None & Invalda (Finasta) & Lithuania \\
\hline Danske Capital Investment Management & Lithuania & Ownership & Danske Bank & Denmark \\
\hline
\end{tabular}

* Hipo and Land Bank was reorganised into Altum in 2014, which is an special project financing institution

** From 2009 till 2011 there was ownership based integration and from 2012 distribution agreements with banks is in place Source: prepared by the author based on publicly available information
Market players in the Baltic countries and their cluster analysis

\section{Table 1}

Companies subject to research from the Baltic market 2009-2016 
2011, Invalda entered into distribution agreements with several banks and is not linked to those with ownership ties.

The first cluster represents small to medium specialised pension fund companies with none to little exposure to non-pension fund management income (see Table 2). In terms of a number of companies, this is the most representative cluster, which comprises nearly a half of all market players. The cluster clearly benefitted from the tailwind of increasing volume of pension fund assets defined as assets under management range, which increased from 6 to 97 million euro in 2009 up to 62 to 348 million euro in 2015. None of other clusters experienced such a rapid growth of assets under management.

Also the share of non-pension fund management income decreased steadily for the cluster 0 to $18 \%$ in 2009 down to 0 to $26 \%$ in 2015 . The second cluster is formed by two related pension fund companies operating in different countries. The companies are similar in terms of assets under management and almost non-existent income from non-pension fund management activities. The third cluster of companies poses a scientific interest because it ceased to exist as a cluster in 2013. One common thing of these medium in size companies belonging to the cluster is their major exposure to non-pension fund management business. The fourth cluster of companies

Table 2

Summary of the cluster analysis of pension fund management companies in Baltic countries 2009-2015

\begin{tabular}{|c|c|c|c|c|c|c|c|c|}
\hline $\begin{array}{l}\text { Clus- } \\
\text { ter }\end{array}$ & Criterion & 2009 & 2010 & 2011 & 2012 & 2013 & 2014 & 2015 \\
\hline \multirow{2}{*}{1} & $\begin{array}{l}\text { AuM range, mil. } \\
\text { euro }\end{array}$ & $6-97$ & $8-143$ & $31-219$ & $39-252$ & 43-374 & $45-323$ & $62-348$ \\
\hline & $\begin{array}{l}\text { Non-pension } \\
\text { income }\end{array}$ & $0-18 \%$ & $0-36 \%$ & $0-23 \%$ & $0-14 \%$ & $0-11 \%$ & $0-9 \%$ & $0-26 \%$ \\
\hline \multirow{2}{*}{2} & $\begin{array}{l}\text { AuM range, mil. } \\
\text { euro }\end{array}$ & $379-411$ & $426-497$ & $445-512$ & $524-628$ & $548-737$ & $653-930$ & $\begin{array}{l}882- \\
1074\end{array}$ \\
\hline & $\begin{array}{l}\text { Non-pension } \\
\text { income }\end{array}$ & $1-4 \%$ & $0-3 \%$ & $0-2 \%$ & $1-2 \%$ & 0 & $0-9 \%$ & $0-18 \%$ \\
\hline \multirow{2}{*}{3} & $\begin{array}{l}\text { AuM range, mil. } \\
\text { euro }\end{array}$ & $235-441$ & $104-435$ & $92-368$ & 114-166 & - & - & - \\
\hline & $\begin{array}{l}\text { Non-pension } \\
\text { income }\end{array}$ & $44-61 \%$ & $25-55 \%$ & $51-55 \%$ & $50-55 \%$ & - & - & - \\
\hline \multirow{2}{*}{4} & $\begin{array}{l}\text { AuM range, mil. } \\
\text { euro }\end{array}$ & $556-580$ & $608-953$ & $616-633$ & $524-754$ & 770-780 & $504-594$ & $570-734$ \\
\hline & $\begin{array}{l}\text { Non-pension } \\
\text { income }\end{array}$ & $17-19 \%$ & $20-34 \%$ & $17-24 \%$ & $15-16 \%$ & $14-18 \%$ & $15-22 \%$ & $0-36 \%$ \\
\hline \multirow{2}{*}{5} & $\begin{array}{l}\text { AuM range, mil. } \\
\text { euro }\end{array}$ & - & - & - & - & - & $65-250$ & - \\
\hline & $\begin{array}{l}\text { Non-pension } \\
\text { income }\end{array}$ & - & - & - & - & - & $19-22 \%$ & - \\
\hline \multirow{2}{*}{ Outliers } & $\begin{array}{l}\text { AuM range, mil. } \\
\text { euro }\end{array}$ & $52-882$ & 1980 & $846-1300$ & $155-1473$ & $124-1284$ & $139-1100$ & 1287 \\
\hline & $\begin{array}{l}\text { Non-pension } \\
\text { income }\end{array}$ & $31-46 \%$ & 0.47 & $34-47 \%$ & $29-43 \%$ & $27-55 \%$ & $19-40 \%$ & 0.15 \\
\hline
\end{tabular}

Source: prepared by the author based on the single linkage cluster analysis. 
is very similar to the second cluster. However, its main distinction is stable non-pension fund business related stream of income. The final group of companies are so-called outliers. These companies have a big portion on non-pension fund management related income (15-55\%).

In efficiency research of financial sector companies, typically various types of costs were used as input variables whilst various types of revenue and profit indicators used as output variables. Therefore the operational efficiency of the pension fund management companies is performed by using the thirteen models. For the cost and profit models, commission fees as well as administrative fees were used as input variables while profit before tax was used an output variable. One capital efficiency (i.e. actual ROE) model was used. It has to be noted that average actual pre-tax return on equity in 2015 was $28.2 \%$, average pre-tax return on equity in the top efficiency quartile was $60.7 \%$. Capital efficiency model uses actual return (i.e. pre-tax profit) on shareholder equity as the only measure of efficiency. Finally, cost and capital efficiency DEA CRS and VRS as well as SFA models under various ROE scenarios were used. Cost and capital efficiency DEA CRS, VRS and SFA models can be considered to consist of two types of costs being actual costs as well as calculated capital costs. Actual costs of the models comprise administration as well as commission costs as input figures. The calculated capital cost, which was also used as an input figure, stands for economic cost of capital defined as a required pre-tax return on equity, multiplied by average equity in a given year. Following three capital scenarios were used to calculate cost of capital- pre-tax return of equity $11 \%, 15 \%$ and ultimately $19 \%$.

A regression analysis was applied to examine whether bigger assets under management and bigger share of non-pension fund income increase cost efficiency of pension fund management companies. The Table 3 summarises efficiency models as well as main findings of the regression analysis applied for the models. The regression equation is expressed in the following manner:

$$
C E=\beta_{1} * \text { NormAuM }+\beta_{2} * \text { ShareNonPensInc }+\alpha
$$

where $C E$ is cost efficiency score, NormAuM is a figure of normalised assets under management, ShareNonPens/nc is a share of non-pension fund revenue and $a$ stands for intercept. For the capital efficiency model the regression equation was stated in the following manner:

$$
R O E=\beta_{1} * \text { NormAuM }+\beta_{2} * \text { ShareNonPensInc }+\alpha
$$

where ROE is a figure for actual return on equity, NormAuM is a figure of normalised assets under management, ShareNonPens/nc is a share of non-pension fund revenue and a stands for intercept.

The regression analysis applied for results obtained by various models demonstrated that between efficiency score and assets under management and share of non-pension fund management revenue for all the models discussed above correlation coefficients range from 0.05 to 0.42 while adjusted coefficients of determination are in the interval from -0.01 to 0.16 .

DEA CRS models demonstrate the lowest correlation coefficients ranging from 0.05 to 0.25 . The finding speaks in favour of an argument that efficiency scores cannot be explained by volume of assets under management and share of non-pension fund management income. DEA VRS model findings reveal correlation coefficients in a broader range of 0.09 to 0.42 . SFA models

\section{Efficiency models, regression and top quartile analysis}




\begin{tabular}{|c|c|c|c|c|}
\hline & & & & \\
\hline $\begin{array}{r}\text { Table } 3 \\
\text { Regression analysis }\end{array}$ & Model & Correlation & $\begin{array}{c}\text { Adjusted coefficient of } \\
\text { determination }\end{array}$ & Significance \\
\hline scores and volume & 1. Cost and profit DEA CRS & 0.05 & -0.01 & 0.84 \\
\hline management and share & 2. Cost and profit DEA VRS & 0.09 & -0.01 & 0.61 \\
\hline management income & 3. Cost and profit SFA & 0.30 & 0.08 & 0.00 \\
\hline & 4. Capital efficiency (i.e. actual ROE) & 0.25 & 0.05 & 0.02 \\
\hline & 5. Cost and capital efficiency DEA CRS (ROE=11\%) & 0.18 & 0.02 & 0.12 \\
\hline & 6. Cost and capital efficiency DEA CRS (ROE=15\%) & 0.19 & 0.02 & 0.08 \\
\hline & 7. Cost and capital efficiency DEA CRS (ROE=19\%) & 0.25 & 0.05 & 0.02 \\
\hline & 8. Cost and capital efficiency DEA VRS (ROE=11\%) & 0.42 & 0.16 & 0.00 \\
\hline & 9. Cost and capital efficiency DEA VRS (ROE=15\%) & 0.40 & 0.14 & 0.00 \\
\hline & 10. Cost and capital efficiency DEA VRS (ROE=19\%) & 0.38 & 0.13 & 0.00 \\
\hline & 11. Cost and capital efficiency SFA (ROE=11\%) & 0.30 & 0.08 & 0.00 \\
\hline & 12. Cost and capital efficiency SFA (ROE=15\%) & 0.24 & 0.05 & 0.02 \\
\hline & 13. Cost and capital efficiency SFA (ROE=19\%) & 0.30 & 0.07 & 0.01 \\
\hline
\end{tabular}

Source: prepared by the author based on efficiency scores obtained from the defined models.

showed correlation figures varying from 0.24 to 0.30 . Thus such results can be interpreted as not supporting the view that volume and scope contribute to efficiency of pension fund management companies operating under the Bancassurance model in Baltics. Finally, it is noteworthy to mention that nearly all regression models demonstrated strong significance while it was weak for Cost and profit DEA CRS and VRS models.

Furthermore, a detailed analysis of top quartile of companies (i.e. 4-6 companies) with the highest efficiency scores is performed. Summary findings are presented at the cluster level in the Table 4. Total appearance of a given cluster companies during the research period 2009-2015 is stated in percentage terms for each of the efficiency models considered.

Cluster number one companies (i.e. small and medium specialised pension fund management companies) comprise $36 \%-60 \%$ of the total top quartile of companies with the highest efficiency scores with the average representation score of $45 \%$. It also has to be noted that the first cluster is the biggest one comprising nearly half of all pension fund management companies subject to the research. Therefore, such high appearance of the cluster one companies in the top quartile does not guarantee any probabilistic advantage for small and medium companies.

The next most represented cluster is number four, which consists of big pension fund management companies with moderate exposure to non-pension fund management business. The cluster number two, which stands for big pension fund management companies with low exposure to non-pension fund management business, on average is represented twice less frequent compared to the cluster number four. Finally, the cluster number three did not score any strong results because it ceased to exist in 2013 while outliers broadly failed to demonstrate sufficiently competitive efficiency to earn their place in the top quartile.

As concluding remarks, it can be stated there was evidence obtained that on average there is weak correlation (i.e. 0.26 ) between efficiency scores obtained by using thirteen models and 


\begin{tabular}{|c|c|c|c|c|c|c|c|}
\hline \multirow{2}{*}{ Model } & \multicolumn{6}{|c|}{ Clusters } & \multirow{2}{*}{ Total } \\
\hline & 1 & 2 & 3 & 4 & 5 & Outliers & \\
\hline 1. Cost and profit DEA CRS & $60 \%$ & $9 \%$ & $9 \%$ & $20 \%$ & $0 \%$ & $3 \%$ & $100 \%$ \\
\hline 2. Cost and profit DEA VRS & $59 \%$ & $6 \%$ & $6 \%$ & $25 \%$ & $0 \%$ & $5 \%$ & $100 \%$ \\
\hline 3. Cost and profit SFA & $37 \%$ & $20 \%$ & $6 \%$ & $31 \%$ & $0 \%$ & $6 \%$ & $100 \%$ \\
\hline 4. Capital efficiency (i.e. actual ROE) & $39 \%$ & $23 \%$ & $5 \%$ & $33 \%$ & $0 \%$ & $0 \%$ & $100 \%$ \\
\hline 5. Cost and capital efficiency DEA CRS (ROE=11\%) & $51 \%$ & $14 \%$ & $3 \%$ & $31 \%$ & $0 \%$ & $0 \%$ & $100 \%$ \\
\hline 6. Cost and capital efficiency DEA CRS (ROE=15\%) & $46 \%$ & $20 \%$ & $3 \%$ & $31 \%$ & $0 \%$ & $0 \%$ & $100 \%$ \\
\hline 7. Cost and capital efficiency DEA CRS (ROE=19\%) & $37 \%$ & $23 \%$ & $6 \%$ & $34 \%$ & $0 \%$ & $0 \%$ & $100 \%$ \\
\hline 8. Cost and capital efficiency DEA VRS (ROE=11\%) & $43 \%$ & $19 \%$ & $3 \%$ & $19 \%$ & $0 \%$ & $16 \%$ & $100 \%$ \\
\hline 9. Cost and capital efficiency DEA VRS (ROE=15\%) & $44 \%$ & $20 \%$ & $0 \%$ & $20 \%$ & $0 \%$ & $17 \%$ & $100 \%$ \\
\hline 10. Cost and capital efficiency DEA VRS (ROE=19\%) & $36 \%$ & $25 \%$ & $3 \%$ & $19 \%$ & $0 \%$ & $17 \%$ & $100 \%$ \\
\hline 11. Cost and capital efficiency SFA (ROE=11\%) & $49 \%$ & $17 \%$ & $3 \%$ & $31 \%$ & $0 \%$ & $0 \%$ & $100 \%$ \\
\hline 12. Cost and capital efficiency SFA (ROE=15\%) & $46 \%$ & $14 \%$ & $6 \%$ & $34 \%$ & $0 \%$ & $0 \%$ & $100 \%$ \\
\hline 13. Cost and capital efficiency SFA (ROE=19\%) & $43 \%$ & $17 \%$ & $6 \%$ & $34 \%$ & $0 \%$ & $0 \%$ & $100 \%$ \\
\hline Average representation & $45 \%$ & $17 \%$ & $4 \%$ & $28 \%$ & $0 \%$ & $5 \%$ & - \\
\hline
\end{tabular}

Table 4

Composition of top quartile by clusters of different companies 2009-2015

volume of assets under management and share of non-pension fund management income of pension fund management companies. Additionally, the cluster analysis combined with the analysis of top quartile of companies with the highest efficiency scores demonstrated capability of small and medium pension fund management companies to be sufficiently represented in the top quartile in a sustainable manner.

Even though common trends may be identified within the results of the models discussed above, it is very important to examine statistical correlation among those to check consistency of results. To proceed, nine ordinary least square regression equations are established as follows:

$$
C E\left(\text { Model }_{i} \operatorname{ROE}_{i}\right)=\beta_{1} * C E\left(\text { Model }_{i+1} \operatorname{ROE}_{i}\right)+\alpha
$$

where CE(Model) denotes a cost efficiency score of the starting model with assumed ROE, $C E\left(\right.$ Model $\left._{i+1}\right)$ stands for a cost efficiency score of the next model under the same assumption of return on equity $i$ while $\beta$, is a coefficient and $a$ stands for an intercept value. Regression analysis findings are summarised in the Table 5.

The regression equations revealed medium and strong correlation, what confirms that results of the various efficiency assessment models can be considered to be consistent. Additionally, the regression equations were found to be significant. Correlation coefficients of regression equations, which are based on SFA and DEA CRS, range from 0.51 to 0.88 and are effectively higher than those of equations based on SFA and DEA VRS, ranging from 0.48 to 0.72 . It demonstrates the 


\begin{tabular}{|c|c|c|c|c|}
\hline \multirow{13}{*}{$\begin{array}{r}\text { Table } 5 \\
\text { Regression analysis } \\
\text { findings }\end{array}$} & Regression & $\begin{array}{l}\text { Correla- } \\
\text { tion }\end{array}$ & $\begin{array}{l}\text { Adjusted coefficient } \\
\text { of determination }\end{array}$ & $\begin{array}{l}\text { Signifi- } \\
\text { cance }\end{array}$ \\
\hline & Cost and profit SFA and DEA CRS & 0.51 & 0.25 & 0.00 \\
\hline & Cost and profit SFA and DEA VRS & 0.48 & 0.23 & 0.00 \\
\hline & Cost and profit DEA CRS and DEA VRS & 0.67 & 0.45 & 0.00 \\
\hline & Cost and capital efficiency (ROE=11\%) SFA vs. DEA CRS & 0.83 & 0.69 & 0.00 \\
\hline & Cost and capital efficiency (ROE=11\%) SFA vs. DEA VRS & 0.65 & 0.41 & 0.00 \\
\hline & Cost and capital efficiency (ROE=11\%) DEA VRS vs. DEA CRS & 0.75 & 0.56 & 0.00 \\
\hline & Cost and capital efficiency (ROE=15\%) SFA vs. DEA CRS & 0.88 & 0.78 & 0.00 \\
\hline & Cost and capital efficiency (ROE=15\%) SFA vs. DEA VRS & 0.72 & 0.52 & 0.00 \\
\hline & Cost and capital efficiency (ROE=15\%) DEA VRS vs. DEA CRS & 0.77 & 0.60 & 0.00 \\
\hline & Cost and capital efficiency (ROE=19\%) SFA vs. DEA CRS & 0.80 & 0.63 & 0.00 \\
\hline & Cost and capital efficiency (ROE=19\%) SFA vs. DEA VRS & 0.70 & 0.48 & 0.00 \\
\hline & Cost and capital efficiency (ROE=19\%) DEA VRS vs. DEA CRS & 0.83 & 0.68 & 0.00 \\
\hline
\end{tabular}

Source: prepared by the author.

pattern that returns to scale are rather constant than variable. Variable models might include at the same time increasing and decreasing returns to scale. Finally, a strong correlation found for DEA CRS and VRS efficiency scores also confirms the pattern of returns to scale, which are rather be constant. The correlation range is 0.67-0.83.

Based on the efficiency assessment concept model of the research, several key conclusions are drawn in relation to Bancassurance efficiency in the pension fund management in the Baltic countries:

- Bancassurance is the dominant business model in the pension fund management in Baltics. Seventeen out of twenty pension fund management companies in Baltics operate under the Bancassurance. Sixteen companies operating under the Bancassurance have ownership based integration with banks whilst only one company has been tied to banks by distribution agreements.

- Pension fund management business is very important for financial groups operating in the Baltic countries because it generates very strong return on equity with an average pre-tax figure of $28.2 \%$ (eg., average for the top quartile reached 60.7\%) for 2015 while the traditional banking business typically earns above $5 \%$ and normally does not exceed $12 \%$ per annum.

- Pension fund management companies in Baltics can be classified into four sustainable groups: small and medium specialised companies, big companies with low exposure to non-pension fund management business, big companies with low to moderate exposure to non-pension fund management business, other companies, including outlier companies, which do not fit into any of the above mentioned groups.

_ Small and medium specialised pension fund companies proved to be capable of achieving competitive efficiency compared to other companies because these were presented in the top quartile of companies with highest efficiency rankings throughout the research period on average comprising $45 \%$ of the quartile member companies. 
Aiello, F., Bonanno, G. (2016), "Bank efficiency and local market conditions. Evidence from Italy", Journal of Economics and Business, 83, 70-90. https:// doi.org/10.1016/j.jeconbus.2015.09.002

Aigner, D. J., Lovell, C. A. K., Schmidt P. J. (1977), "Formulation and estimation of stochastic frontier production function models", Journal of Econometrics, 6, 21-37. https://doi.org/10.1016/03044076(77)90052-5

Banker, R. D., Charnes, A., Cooper, W. W. (1984), "Some models for estimating technical and scale inefficiencies in data envelopment analysis", Management Science, 30, 1078-1092. https://doi. org/10.1287/mnsc.30.9.1078

Battese, G.E., Corra, G.S. (1977). Estimation of a production frontier model: with application to the pastoral zone of Eastern Australia. Australian Journal of Agricultural and Resource Economics, 21, 169-179. https://doi.org/10.1111/j.1467-8489.1977.tb00204.x

Bauer, P. W., Berger, A. N., Ferrier, G. D., Humphrey, D. B. (1998), "Consistency Conditions for Regulatory Analysis of Financial Institutions: A Comparison of Frontier Efficiency Methods", Journal of Economics and Business, 50, (2), 85-114. https://doi. org/10.1016/S0148-6195(97)00072-6

Beccalli, E., Casu, B., Girardone, C. (2006), “Efficiency and Stock Performance in European Banking", The Journal of Business, Finance and Accounting, 33, 218-235. https://doi.org/10.1111/j.14685957.2006.01362.x

Berger, P. G., Ofek, E. (1995), “Diversification's effect on firm value", Journal of Financial economics, 37, 39-65. https://doi.org/10.1016/0304405X(94)00798-6

Berry-Stölzle, T. R., Hoyt, R. E., Wende, S. (2013), "Capital Market Development, Competition, Property Rights, and the Value of Insurer Product-Line Diversification: A Cross-Country Analysis", Journal of Risk and Insurance, 80(2), 423-459. https://doi. org/10.1111/j.1539-6975.2012.01470.x

Bikker, J. A., Leuvensteijn, M. Van. (2008), “Competition and efficiency in the Dutch life insurance industry", Applied Economics, (40), 2063-2048. https://doi.org/10.1080/00036840600949298

Carter, J. R. (1977), "In search of synergy: a structure-performance test", The Review of Economics and Statistics, 59, 279-289. https://doi. org/10.2307/1925046

Casu B., Girardone C. (2002), “A Comparative Study of the Cost Efficiency of Italian Bank Conglomer- ates", Managerial Finance, 28 (3), 3-23. https://doi. References
Charnes, A., Cooper, W. W., Rhodes E. (1978), "Measuring the efficiency of decision making units", European Journal of Operational Research, 2, 429-444. https://doi.org/10.1016/03772217(78)90138-8

Clipici, E., Bolovan, C. (2012), “Bancassurance Main Insurance Distribution and Sale Channel in Europe", Scientific Bulletin - Economic Sciences, 11, Special Issue.

Coelli, T., Prasada, D. S., O'Donnel, C. J., Battese, G. E. (2005), An Introduction to Efficiency and Productivity Analysis. Second Edition, Springer, New York.

Davis, S. I. (2007), Bancassurance: The Lessons of Global Experience in Banking and Insurance Collaboration, VRL KnowledgeBank Ltd, London.

Deutsche Bundesbank. (2006), "The cost efficiency of German banks: a comparison of SFA and DEA", Discussion paper, 2 (10).

Du, K., Sim., N. (2016), "Mergers, acquisitions, and bank efficiency: Cross-country evidence from emerging markets", Research in International Business and Finance, 36, 499-510. https://doi. org/10.1016/j.ribaf.2015.10.005

Färe, R., Grosskopf, S., Logan, J. (1983) “The Relative Efficiency of Illinois Electric Utilities", Resources and Energy, 5, 349-367. https://doi. org/10.1016/0165-0572(83)90033-6

Farrell, M. J. (1957), "The Measurement of Productive Efficiency", Journal of the Royal Statistical Society. Series A (General), 120 (3), 253-290. https:// doi.org/10.2307/2343100

Ferrier, G. D., Lovell, C. A. K. (1990), "Measuring Cost Efficiency in Banking: Econometric and Linear Programming Evidence", Journal of Econometrics, 46(1/2), 229-245. https://doi.org/10.1016/03044076(90)90057-Z

Fiordelisi, F., Ricci, O. (2009), "Bancassurance efficiency gains in the insurance industry: the Italian case". Retrieved from https://www.rese archgate.net/ publication/238704598_Bancassurance_efficiency_ gains_in_the_insurance_industry_the_Italian_case.

Grant, R. M., Jammine, A.P. (1988), "Performance differences between the Wrigley/Rumelt strategic categories", StrategicManagement Journal, 9, 333-346. https://doi.org/10.1002/smj.4250090404

Greene, W. (1997), "Frontier Production Functions", in Pesaran, M. H., Schmidt, P., Handbook of Applied Econometrics. 
Hackethal, A. (2004), "German banks and banking structure", in Krahnen, J., Schmidt, R. (Eds.), The German Financial System, Oxford University Press, Oxford, 387-424. https://doi. org/10.1093/0199253161.003.0003

Hughes, J. P., Mester, J. (2013), “Who said large banks don't experience scale economies? Evidence from a risk-return-drivencost function", Journal of Financial Intermediation, 22, 559-585. https://doi. org/10.1016/j.jfi.2013.06.004

Lang, L. H. P., Stulz, R. M. (1994), “Tobin's Q, corporate diversification and firm performance, Journal of Political Economy, 102, 1248-1280. https://doi. org/10.1086/261970

Meeusen, W., van den Broeck, J. (1977), “Efficiency Estimation from Cobb-Douglas production functions with composed error", International Economic Review, 18, 435-444. https://doi. org/10.2307/2525757

Moradi-Motlagh, A., Babacan, A. (2015), "The impact of the global financial crisis on the efficiency of Australian banks", Economic Modelling, 46, 397-406. https://doi.org/10.1016/j.econmod.2014.12.044

Nawi, M. A. A., Ahmad, W. M. A. W., Aleng, N. A. (2012), "Efficiency of General Insurance in Malaysia Using Stochastic Frontier Analysis", International Journal of Modern Engineering Research, 2(5), 3886-3890.

Pinter, E. (2013), "Strategic and Marketing Aspect of Bancassurance - Service. Innovation in Hungary”, International Proceedings of Economics Development and Research, 59, 126-130.
Preckova, L. (2016), “Evaluation of Bancassurance Functioning in Selected Countries of the Financial Groups Erste Group Bank and UniCredit Group", Financial Assets and Investing Journal, 7(2), 19-33. https://doi.org/10.5817/FAl2016-2-2

Resti, A. (1997), "Evaluating the Cost Efficiency of the Italian Banking System: What can be learned from the Joint Alpplication of Parametric and Nonparametric Techniques", Journal of Banking \& Finance, 21, 221-250. https://doi.org/10.1016/ S0378-4266(96)00036-2

Rummelt, J. R. (1974). Estimating the Efficiency of Production. International Strategy, Structure and Economic Performance. Harvard Business School, Cambridge.

Sheldon, G. (1994), “Economies, Inefficiencies and technical progress in Swiss Banking", in Fair, D.E, Raymond, R. (Ed.), The Competitiveness of Financial Institutions and Centres in Europe, Kluwer Academic Publishers, Boston, pp. 115-133. https:// doi.org/10.1007/978-94-015-8350-3_8

Titko, J., Stankeviciene, J, Lace, N. (2014), “Measuring bank efficiency: DEA application”, Technological and Economic Development of Economy, 20(4), 739-757. https://doi.org/10.3846/20294913 .2014 .984255

Weill, L. (2004), "Measuring Cost Efficiency in European Banking: A Comparison of Frontier Techniques", Journal of Productivity Analysis, 21, 133-152. https://doi.org/10.1023/ B:PROD.0000016869.09423.0c

\section{About the author \\ AREFJEVS ILJA \\ Dr. sc. administr. \\ BA School of Business of Finance}

Fields of research interests

Finance, investments

\section{Address}

K.Valdemara 161, Riga, LV1013, Latvia

Tel. +37126547036 